\title{
Plasma Membrane from Muskmelon Leaves: Purification and Lipid Composition during Growth at 15 or 30C
}

\author{
Gene Lester \\ Subtropical Agricultural Research Laboratory, Agricultural Research Service, U.S. Department of \\ Agriculture, 2301 S. International Boulevard, Weslaco, TX 78596
}

Additional index words. aqueous polymer two-phase partitioning, ATPase, protein, sterols, phospholipids, fatty acids, Cucumis melo

\begin{abstract}
Using an aqueous polymer two-phase [polyethylene glycol (PEG) 3400/dextran T500, 6.2\%: 6.2\%, w/w] partitioning procedure combined with isopycnic fractionation, plasma membranes derived from muskmelon (Cucumis melo L. var. reticulates Naud.) leaf blades have been isolated and examined for marker enzyme activity, density, and molecular composition. After aqueous polymer partitioning, plasma membranes were centrifuged on a linear sucrose density gradient, and a single band was found at the $31 \%(\mathrm{w} / \mathrm{w})$ sucrose $\left(1.13 \mathrm{~g}-\mathrm{cm}^{-3}\right)$. Identification of plasma membranes was performed by the combination of $\mathrm{K}^{+}$-stimulated ATPase, $\mathrm{pH}$ 6.5, vanadate inhibition of ATPase and $\mathrm{KNO}_{3}$-insensitive ATPase activity. Plasma membranes from seedling leaves grown for 5 days at $15 \mathrm{C}$ had the highest concentration of total phospholipids, the lowest concentration of proteins, and a total sterol concentration not significantly different from leaves grown at 30C. The total sterol to total phospholipid ratio of the plasma membrane from leaves grown for 5 days at $15 \mathrm{C}$ was $\approx 1: 1$; from leaves grown for 10 days at $15 \mathrm{C}$ or 5 days at $30 \mathrm{C}$ the ratio was $\approx 2: 1$; and from leaves grown for 10 days at $30 \mathrm{C}$ the ratio was $\approx 3: 1$. The plasma membrane phospholipid saturated to unsaturated fatty acid ratio from leaves grown for 5 days at $15 \mathrm{C}$ was $\approx 0.8: 1.0$; from leaves grown for 10 days at $15 \mathrm{C}$ or 5 days at $30 \mathrm{C}$ the ratio was $\approx 1.0: 1.0$; and from leaves grown for 10 days at $30 \mathrm{C}$ it was 1.4:1.0.
\end{abstract}

Gombos and Vigh (1986) have shown that the plasma membrane of blue-green algae has the primary role in thermal adaptation of this organism. There is evidence to indicate that the plasma membrane of Cucumis melo L. is directly involved in heat acclimation of muskmelon leaves (Lester, 1985, 1986). However, it appears that age-related changes are more important in enhancing muskmelon leaf cellular thermostability than is growing temperature (Lester, 1986). This fact indicates that the dynamics of membrane reorganization during development are the probable mechanism regulating muskmelon leaf thermostability.

Isolation and purification of plasma membrane are essential for measurement of heat- and age-related effects on membrane molecular composition. In this study, an aqueous polymer twophase partitioning system in tandem with a linear sucrose density gradient was used to obtain relatively pure, chlorophyll-free plasma membrane isolates from green muskmelon leaves. The purpose of this study was to isolate, purify, and characterize the plasma membrane from muskmelon leaves grown at 15 or $30 \mathrm{C}$ for 5 or 10 days in order to directly measure the influence of growing temperature and aging on plasma membrane molecular composition.

\section{Materials and Methods}

Plant material. 'Perlita' muskmelon seeds were germinated and grown in 1 vermiculite : 1 sphagnum peat (v/v) and were fertilized as described by Lester and Dunlap (1985). Seedlings were grown in a glasshouse at $20 \mathrm{C}$ minimum nights and $35 \mathrm{C}$ maximum days under a 12-hr photoperiod supplemented with (300 $\left.\mu \mathrm{mol} \cdot \mathrm{s}^{-1} \cdot \mathrm{m}^{-2}\right)$ high-pressure sodium lights. After first true leaf emergence, the seedlings were moved to growth chambers

Received for publication 3 Apr. 1989. Mention of a proprietary product does not constitute endorsement or recommendation for use by the USDA. The cost of publishing this paper was defrayed in part by the payment of page charges. Under postal regulations, this paper therefore must be hereby marked advertisement solely to indicate this fact. held at either 15 or $30 \pm 2 \mathrm{C}$ with $85 \% \pm 3 \% \mathrm{RH}$ and a $12-\mathrm{hr}$ photoperiod $\left(440 \mu \mathrm{mol} \cdot \mathrm{s}^{-1} \cdot \mathrm{m}^{-2}\right)$ for 5 or 10 days.

Isolation of membranes. All procedures were a modification of Kjellbom and Larsson (1984) and were carried out at 4C. Leaf blades without petioles (75 g) were washed in ice-cold water for 5 rein, then torn and placed in a mortar with $250 \mathrm{ml}$ homogenizing buffer: $0.5 \mathrm{mM}$ sucrose, $50 \mathrm{mM}$ Hepes- $\mathrm{KOH}, \mathrm{pH}$ $7.5,5 \mathrm{mM}$ ascorbic acid, $5 \mathrm{mM}$ EDTA , $5 \mathrm{mM}$ dithiothreitol (DTT), and $0.6 \%(\mathrm{w} / \mathrm{v})$ polyvinylpolypyrrolidone (PVPP). Ascorbic acid and PVPP were added just before homogenization. Leaf blades were macerated in the homogenizing medium for 5 min with a pestle, placed under vacuum for 10 rein, then macerated an additional $5 \mathrm{~min}$. The material was transferred to a tall beaker and homogenized for $30 \mathrm{sec}$ at medium speed, using a Polytron homogenizer (Brinkman Instr., Westbury, N. Y.) equipped with a PTA-50 generating probe. The homogenate was filtered through two layers of Miracloth (Calbiochem, La Jolla, Calif.) and centrifuged at $14,000 \times g$ for $20 \mathrm{~min}$. A microsomal pellet was obtained from the $14,000 \times g$ supernatant by centrifugation at $100,000 \times \mathrm{g}$ for $30 \mathrm{~min}$. This pellet was homogenized at the slowest speed, using a Polytron homogenizer, in $10 \mathrm{ml}$ of suspension buffer: $0.33 \mathrm{M}$ sucrose, $3 \mathrm{mM} \mathrm{KC1}$, and 5 mM potassium phosphate, $\mathrm{pH}$ 7.8. The homogenized suspension $(9 \mathrm{~g})$ was added to $27 \mathrm{~g}$ aqueous polymer buffer containing $6.2 \%(\mathrm{w} / \mathrm{w}$ ) dextran T500, 6.2\% (w/w) PEG 3400 at final weight. The phase system was mixed well and phase separation was accelerated by centrifugation in a swinging bucket centrifuge at 1500x g for $3 \mathrm{~min}$. Upper and lower phases were separated and the lower phase was washed with equal volumes of $6.2 \%(\mathrm{w} /$ w) fresh upper phase. The upper phases were washed with equal volumes of fresh $6.2 \%$ lower phase until a chlorophyll-free preparation was achieved (about three washes). The upper phases were pooled and a plasma membrane-enriched pellet was recovered by centrifugation at $100,000 \times g$ for $30 \mathrm{~min}$. The lower phases plus interface material were pooled, and the intercellular material was pelleted at $100,000 \times g$ for $30 \mathrm{~min}$. Individual pellets were suspended in $1 \mathrm{ml}$ of assay buffer: $250 \mathrm{~mm}$ sucrose, 
$25 \mathrm{~mm}$ Tris-Mes, $1 \mathrm{mM}$ EDTA, and $5 \mathrm{mM}$ DTT and kept on ice for immediate use or pelleted, flushed with $\mathrm{N}_{2}$, and stored at $-80 \mathrm{C}$. Protein content of membrane fractions was determined by the method of Bradford (1976). Chlorophyll was determined on both upper- and lower-phase pellets according to the modified aqueous acetone procedure of Arnon (1949). Pellets were extracted in $1 \mathrm{ml} 80 \%(\mathrm{v} / \mathrm{v})$ acetone at room temperature, centrifuged at $25,000 \times g$ for $10 \mathrm{~min}$ and absorbance was measured according to the modified formula: [( $\left.A_{645} A{ }_{710}\right)$ $\left.0.0202+\left(A_{663}-A_{710}\right) 0.00802\right] / \mathrm{mg}$ protein $\times$ dilution.

Enzyme analysis. ATPase (EC 3.6.1.8) was assayed at $\mathrm{pH}$ 6.5 or 9.0 and $38 \mathrm{C}$ by the method described in Hodges et al. (1972), 1-ml reaction mixtures contained 3 mm Tris·ATP, 3 $\mathrm{mM} \mathrm{MgSO}_{4}, 30 \mathrm{~mm}$ Tris.Mes $\pm 50 \mathrm{~mm} \mathrm{KCI}$. The pH-activity profile required $100 \mathrm{~mm}$ Tris·Mes. UDPase (EC 3.6.1.6) was assayed at pH 6.5 and $38 \mathrm{C}$ as described by Nagahashi and Seibles (1986); 1-ml reaction mixtures contained 3 mm UDPase, $3 \mathrm{~mm} \mathrm{MnSO}_{4}, 30 \mathrm{~mm}$ Tris-Mes $\pm 0.03 \%$ (v/v) Triton X-100. ATPase and UDPase enzyme assays were stopped by adding 2 $\mathrm{ml}$ of $2 \mathrm{~N} \mathrm{HCI}$ containing $1.25 \%(\mathrm{w} / \mathrm{v})$ ammonium molybdate. Inorganic phosphate was determined by the method described in Peterson (1978). Monovalent ion stimulation of ATPase activity was assayed in the same manner as ATPase ( $\mathrm{pH}$ 6.5) activity by adding either $50 \mathrm{~mm}$ solutions of $\mathrm{KCl}, \mathrm{NaCl}, \mathrm{RbCl}$, or Tris.Cl. Latency of K-stimulated, Mg-dependent ATPase activity was assayed in the same manner as ATPase (ph 6.5) activity $\pm 50 \mathrm{mM} \mathrm{KCI}$, plus $0 \%, 0.01 \%, 0.02 \%, 0.05 \%$, or $0.10 \%$ Tritron X-100. Nucleoside diphosphatase or triphosphatase was assayed in the same manner as ATPase ( $\mathrm{pH}$ 6.5) activity using $3 \mathrm{~mm}$ solutions of ADP, CTP, IDP, GTP, or UTP as substrate. Vanadate and nitrate effect on ATPase was assayed by adding to the assay $0.1 \mathrm{~mm}$ vanadate in the presence of 50 $\mathrm{mm} \mathrm{KCl}$ or $50 \mathrm{mM} \mathrm{KNO}_{3}$ without $\mathrm{KCI}$ as described by Bennett et al. (1982).

Isopycnic sucrose density gradient. Upper-phase plasma membrane-enriched pellets were suspended in $2 \mathrm{ml}$ of storage buffer modified to $20 \%$ sucrose (w/w) then layered on a $36-\mathrm{ml}$ linear sucrose gradient of $20 \%$ to $50 \%$ (w/w) sucrose in $40 \mathrm{~mm}$ Tris-Mes, $1 \mathrm{mM}$ EDTA ( $\mathrm{pH} 8.0$ ), and $1 \mathrm{mM}$ DTT, then centrifuged at $75,000 \times g$ for $15 \mathrm{hr}$ at $2 \mathrm{C}$. After centrifugation, 1.5$\mathrm{ml}$ fractions were collected from the bottom of the gradient with a proportioning pump at a flow rate of $0.5 \mathrm{ml} \cdot \mathrm{min}^{-1}$ at $4 \mathrm{C}$.

Total sterol and phospholipid determination. Lipids were extracted from isolated gradient fraction using the procedure of Uemura and Yoshida (1984). Total sterols were eluted through a Sep-Pak silica cartridge (Waters Assoc. Inc., Milford, Mass.) by adding $5 \mathrm{ml}$ of chloroform, then $3 \mathrm{ml}$ of $10 \%$ acetone in chloroform. Acylated steryl glycosides and diglycerides, if present, were eluted by addition of $10 \mathrm{ml}$ of acetone. Phospholipids were eluted by addition of $10 \mathrm{ml} 1$ chloroform : 1 methanol ( $\mathrm{v} /$ $\mathrm{v}$ ), followed by $10 \mathrm{ml}$ of methanol. Quantitative analyses of sterols were performed according to Zlatkis and Zak (1969) by dissolving sterols in $5 \mathrm{ml}$ of chloroform, $3 \mathrm{ml}$ of acetic anhydride, and $0.1 \mathrm{ml}$ of concentrated sulfuric acid for $10 \mathrm{~min}$ in darkness. The absorbance was measured at $415 \mathrm{~nm}$ and campesterol was used as the standard. Quantitative analyses of phospholipids was preformed according to Peterson (1978).

Fatty acid determination. Further purification of phosphoIipids involved TLC separation along with phospholipid standards on nonactivated silica Gel G plates (Analabs, Norwalk, Corm.) developed at 21C in filter-lined chambers with a 130:60:8 solvent system of chloroform, methanol, and $7 \mathrm{~N}$ sodium hydroxide, (by volume), respectively. Phospholipids were visu- alized with Rhodamine $6 \mathrm{G}$ and then scraped from the plate and methylesters were prepared by the transesterification $\mathrm{BCl}_{3}-\mathrm{MeOH}$ method of Klopfenstein (1971). Fatty acid methylesters were analyzed by GC using a supelcowax 10 (Supelco, Inc. Bellefonte, Pa.) capillary column $30 \mathrm{M} \times 0.25 \mu \mathrm{m}$ and quantified using methyl heptadecanoate as the internal standard.

\section{Results}

The upper- (PEG 3400) and lower- (dextran T500) phase separation in the $6.2 \%: 6.270(\mathrm{w} / \mathrm{w})$ phase system showed that $89 \%$ of the plasma membrane marker activity was recovered in the upper phase (Table 1). Only $10 \%$ of the Golgi body marker (Triton X-100 stimulated UDPase, pH 6.5), no endoplasmic reticulum or mitochondrial marker (NADH-cytochrome-C reductase and ATPase, $\mathrm{pH}$ 9.0, respectively), and no chlorophyll was recovered in this upper fraction. Tonoplast membrane marker ( $\mathrm{KNO}_{3}$ inhibition of ATPase) was determined just on the upperphase fraction (data not shown) and demonstrated no activity. The lower-phase fraction, which should contain all microsomal membranes, except the plasma membrane, showed $100 \%, 81 \%$, and $12 \%$ of the total activity for markers of ER, mitochondria, Golgi body, and plasma membrane, respectively, and 100\% for chlorophyll content (Table 1). Table 2 shows the nucleotide and monovalent ion specificity of the plasma membrane ATPase. The greatest nucleotide activity occurred with ATPase, and with GTPase showing $48 \%$ of the ATPase activity. The greatest monovalent ion stimulation of ATPase occurred with KCI, with the activity measured in the presence of $\mathrm{Na}^{+}$being $84 \%$ of the activity measured in the presence of $\mathrm{K}^{+}$.

The $\mathrm{pH}$ curves for ATPase activity assayed on upper-phase fractions were highest at 6.5 with $\mathrm{KCI}$ and at 7.0 without $\mathrm{KCl}$ (data not shown). Depending on $\mathrm{pH}$, the specific activity of $\mathrm{Mg}$-ATPase marker was increased $8 \%$ to $16 \%$ in the presence of $\mathrm{KCl}$. The specific activity of KCl-stimulated Mg-ATPase $(\mathrm{pH}$ 6.5) activity was stimulated by $0.01 \%$ and inhibited by $0.1 \%$ Triton X-100 (data not shown).

In the presence of DTT, plasma membrane, and Golgi body marker, phosphohydrolase activity was preserved. Otherwise, $>30 \%$ reduction in phosphohydrolase activity would occur following isolation and isopycnic centrifugation (data not shown).

Upper-phase, plasma membrane-enriched pellets fractionated over a linear sucrose gradient of $20 \%$ to $50 \%$ (Fig. 1A), showed that protein was concentrated in the linear fractions corresponding to densities between 1.11 to $1.14 \mathrm{~g} \cdot \mathrm{cm}^{-3}$ (Fig. 1B). The peak concentration of protein occurred at a density of $1.13 \mathrm{~g} \cdot \mathrm{cm}^{-3}$. The greatest phophohydrolase activity of the plasma membrane marker was coincident with the protein peak (Fig. 1C). The Mg-ATPase, $\mathrm{pH} 6.5$ minus $\mathrm{KCl}$, also co-fractionated at 1.13 $\mathrm{g} \cdot \mathrm{cm}^{-3}$ and had $\approx 13 \%$ less specific activity when compared to the KCl-stimulated Mg-ATPase activity. Inhibitors of ATPase were tested on all protein-enriched sucrose gradient fractions (Fig. 1D). Vanadate, as $\mathrm{Na}_{3} \mathrm{~V} \mathrm{O}_{4}$ inhibited the plasma membrane-associated $\mathrm{KCl}-\mathrm{Mg}$-ATPase activity by $>80 \%$, whereas $\mathrm{NO}_{3}$, an inhibitor of tonoplast marker, had no effect. The Golgi membrane marker, Triton-stimulated UDPase at $\mathrm{pH}$ 6.5, showed the greatest activity within fractions of 1.11 to $1.12 \mathrm{~g} \cdot \mathrm{cm}^{-3}$ and almost no activity at the density of $1.13 \mathrm{~g} \cdot \mathrm{cm}^{-3}$ (Fig. 1E).

Plasma membrane fractions from leaves grown for 5 days at $15 \mathrm{C}$ had the highest concentration of total phospholipids, the lowest concentration of proteins, and total sterols nearly equal in concentration to the plasma membrane from leaves grown for 5 or 10 days at $30 \mathrm{C}$ (Table 3 ). The plasma membrane sterol to phospholipid ratio $(\mu \mathrm{mol}: \mu \mathrm{mol})$ increased as growing tem- 
Table 1. Specific phosphohydrolase activity ( $\mu \mathrm{mol} \mathrm{Pi/mg} \mathrm{per} \mathrm{hr)} \mathrm{and} \mathrm{total} \mathrm{phosphohydrolase} \mathrm{activity} \mathrm{( \% )} \mathrm{and} \mathrm{chlorophyll} \mathrm{concentration}$ associated with muskmelon leaf microsomal membranes partitioned into aqueous two-phase polymer, PEG 3400 (upper) or dextran-T500 (lower) 6.2\%:6.2\% (w/w). Plasma membrane marker (Mg-ATPase $\mathrm{pH} 6.5$ plus $\mathrm{KCl}$ ), endoplasmic reticulum marker (NADH cytochrome$C$ reductase), and Golgi body marker (UDPase pH 6.5 plus Triton X).

\begin{tabular}{|c|c|c|c|c|c|c|c|c|}
\hline \multirow[b]{2}{*}{ Phase } & \multicolumn{2}{|c|}{$\begin{array}{c}\text { Mg-ATPase } \\
\text { pH } 6.5 \\
\text { plus } \mathrm{KCl} \\
\end{array}$} & \multicolumn{2}{|c|}{$\begin{array}{c}\text { NADH } \\
\text { cytochrome- } C \\
\text { reductase }\end{array}$} & \multicolumn{2}{|c|}{$\begin{array}{c}\text { UDPase } \\
\text { pH } 6.5 \text { plus } \\
\text { Triton X } \\
\end{array}$} & \multicolumn{2}{|c|}{ Chlorophyll } \\
\hline & $\begin{array}{l}\mu \mathrm{mol} \mathrm{Pi} / \\
\mathrm{mg} \text { per hr }\end{array}$ & $\%$ & $\begin{array}{c}\mu \mathrm{mol} \text { NADH/ } \\
\text { mg per hr }\end{array}$ & $\%$ & $\begin{array}{c}\mu \mathrm{mol} \mathrm{Pi} / \\
\mathrm{mg} \text { per } \mathrm{hr}\end{array}$ & $\%$ & $\mathrm{mg} \cdot \mathrm{mg}^{-1} \cdot \mathrm{ml}^{-1}$ & $\%$ \\
\hline Upper & 63.0 & 89 & 0.0 & 0 & 3.0 & 10 & 0.00 & 0 \\
\hline Lower & 7.7 & 11 & 1.2 & 100 & 26.0 & 90 & 0.23 & 100 \\
\hline
\end{tabular}

Table 2. Nucleotide and monovalent ion specificity of the membranebound ATPase activity from muskmelon leaf plasma membrane isolated by two-phase partitioning and isopycnic sucrose gradients. The liberation of $\mathrm{Pi}$ from the various phosphate substrates at $3 \mathrm{~mm}$ was determined at $37 \mathrm{C}$ and $\mathrm{pH} 6.5 \mathrm{in} 33 \mathrm{mM}$ Tris $\cdot$ Mes and $3 \mathrm{mM} \mathrm{MgSO}_{4}$. Monovalent ion specificity was the same as ATPase plus $50 \mathrm{~mm}$ of the various ions. Specific activity is presented in $\mu$ moles Pi released/ $\mathrm{mg}$ protein per hr.

\begin{tabular}{cccc}
\hline Substrate & $\begin{array}{c}\text { ATPase activity } \\
(\mu \mathrm{mol} \mathrm{Pi} / \mathrm{mg} \text { per hr })\end{array}$ & \multicolumn{1}{c}{ Ion } & $\begin{array}{c}\text { ATPase activity } \\
(\mu \mathrm{mol} \mathrm{Pi} / \mathrm{mg} \text { per hr) }\end{array}$ \\
\hline ATP & 51.0 & $\mathrm{KCl}$ & 12.0 \\
GTP & 24.4 & $\mathrm{NaCl}$ & 2.0 \\
UTP & 21.4 & $\mathrm{RbCl}$ & 0.0 \\
IDP & 18.4 & $\mathrm{Tris} \cdot \mathrm{Cl}$ & 0.0 \\
CTP & 17.9 & & \\
ADP & 14.8 & & \\
\hline
\end{tabular}

perature increased and leaves aged (Table 3). The total sterol to total phospholipid ratio of the plasma membrane from leaves grown for 5 days at $15 \mathrm{C}$ was $50 \%$ that of plasma membrane from leaves grown for 10 days at $15 \mathrm{C}$ or 5 days at $30 \mathrm{C}$ and $\approx 440 \%$ that of plasma membrane from leaves grown for 10 days at $30 \mathrm{C}$. The plasma-membrane phospholipid, saturated to unsaturated fatty acid ratio also increased as growing temperature increased and leaves aged (Table 3). From leaves grown for 5 days at $15 \mathrm{C}$, the plasma-membrane fatty acids were more unsaturated; while from leaves grown for 10 days at $15 \mathrm{C}$ or 5 days at $30 \mathrm{C}$ the fatty acids were nearly equal in saturation to unsaturation, and from leaves grown for 10 days at $30 \mathrm{C}$ the plasmamembrane fatty acids were more saturated.

\section{Discussion}

This investigation has shown that relatively pure plasma membrane from green muskmelon leaves can be "quickly" obtained by aqueous polymer separation in tandem with isopycnic sucrose gradient centrifugation and is suitable for further membrane investigations. Following isopycnic centrifugation, plasma membranes from muskmelon leaves equilibrate at a density of $1.13{\mathrm{~g}-\mathrm{cm}^{-3}}^{-2} \approx 31 \% \mathrm{w} / \mathrm{w}$ sucrose). This density fraction was shown to be free of markers for mitochondrial membrane, Golgi membrane, and tonoplast. The relatively light density for muskmelon leaf plasma membrane was consistent with previous work on green tissues. Pea (Pisum sativum L.) epicotyl (Pierce and Hendrix, 1979) plasma membrane had a density of $1.13 \mathrm{~g}-\mathrm{cm}^{-3}$ and orchard grass (Dactylis glomerata L.) culms (Yoshida and Umera, 1984) had plasma membrane density of 1.14 to 1.15 $\mathrm{g}-\mathrm{cm}^{-3}$ ( $\approx 34 \% \mathrm{w} / \mathrm{w}$ sucrose $)$. Non-green tissues such as oat (Avena sativa L.) roots (Hodges et al., 1972) and etiolated mung

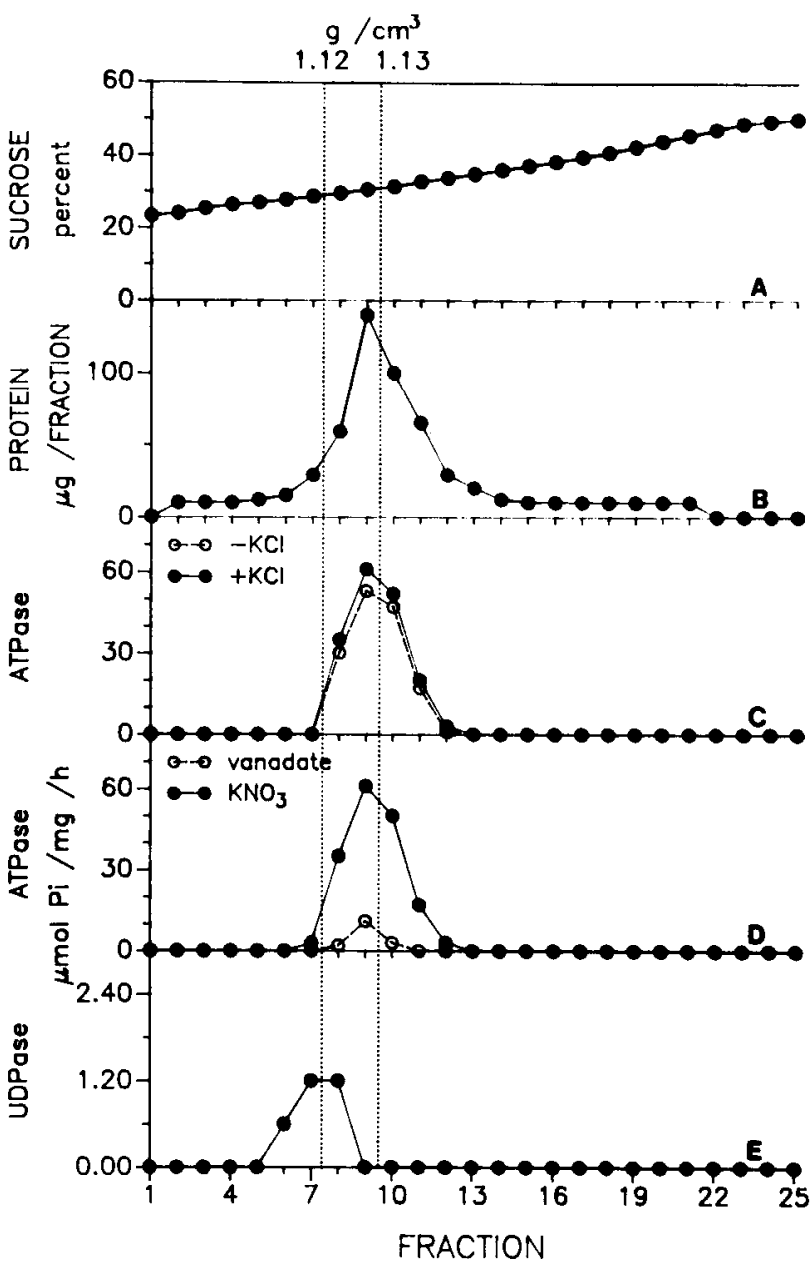

Fig. 1. Sucrose density (20\% to $50 \% \mathrm{w} / \mathrm{w})$ gradients of upper-phase (polyethylene glycol $6.2 \%, \mathrm{w} / \mathrm{w}$ ) fraction membrane pellet from 300 $\mathrm{g}$ (fresh weight) of muskmelon leaf homogenates. A pellet was suspended in $20 \%$ sucrose (w/w), $40 \mathrm{~mm}$ Tris.Mes, pH 8.0, $1 \mathrm{~mm}$ EDTA, $1 \mathrm{mM}$ DTT and centrifuged at $75,000 \times \mathrm{g}$ for $15 \mathrm{hr}$ at $2 \mathrm{C}$, then twenty-five $1.5-\mathrm{ml}$ fractions were collected. (A) Sucrose \%. (B) Protein. (C) ATPase activity assayed at $\mathrm{pH} 6.5 \pm \mathrm{KCl}$. (D) Vanadate or $\mathrm{KNO}_{3}$ inhibition/stimulation of ATPase activity at $\mathrm{pH}$ 6.5. (E) Triton X-100-stimulated UDPase assayed at $\mathrm{pH}$ 6.5. Each value represents six replications.

bean (Vigna radiata L.) hypocotyls (Yoshida et al., 1986) have a plasma membrane density of 1.17 to $1.18 \mathrm{~g} \cdot \mathrm{cm}^{-3}(=38 \%$ to $40 \%$ w/w sucrose).

Compositional analysis of purified plasma membrane indi- 
Table 3. Comparison of the plasma membrane isolated from 'Perlita' muskmelon leaves grown for 5 or 10 days at 15 or $30 \mathrm{C}$ for protein, total sterols ( $\mu \mathrm{mol} / \mathrm{mg}$ membrane), total phospholipids ( $\mu \mathrm{mol} / \mathrm{mg}$ membrane), sterol to phospholipid ratio (sterol : phos) and phospholipid saturated to unsaturated fatty acid ratio (sat : unsat).

\begin{tabular}{cccccc}
\hline $\begin{array}{c}\text { Growing } \\
\text { conditions } \\
\left.\text { Days/temp }\left({ }^{\circ} \mathrm{C}\right)\right]\end{array}$ & $\begin{array}{c}\text { Protein } \\
\left(\mathrm{mg} \cdot \mathrm{g}^{-1} \text { dry wt) }\right.\end{array}$ & $\begin{array}{c}\text { Sterols } \\
\left(\mu \mathrm{mol} \cdot \mathrm{mg}^{-1}\right)\end{array}$ & $\begin{array}{c}\text { Phospholipids } \\
\left(\mu \mathrm{mol} \cdot \mathrm{mg}^{-1}\right)\end{array}$ & $\begin{array}{c}\text { Sterol : Phos } \\
\left(\mu \mathrm{mol} \cdot \mathrm{mg}^{-1}: \mu \mathrm{mol} \cdot \mathrm{mg}^{-1}\right)\end{array}$ & $\begin{array}{c}\text { Fatty acid } \\
(\mathrm{sat}: \text { unsat })\end{array}$ \\
\hline $5 / 15$ & 0.05 & 1.69 & 1.27 & $1.3: 1.0$ & $0.77: 1.0$ \\
$10 / 15$ & 0.11 & 1.24 & 0.52 & $2.6: 1.0$ & $0.98: 1.0$ \\
$5 / 30$ & 0.15 & 1.51 & 0.60 & $2.5: 1.0$ & $1.01: 1.0$ \\
$10 / 30$ & 0.16 & 1.59 & 0.49 & $3.3: 1.0$ & $1.40: 1.0$ \\
LSD $=0.05$ & 0.03 & 0.18 & 0.09 & & \\
\hline
\end{tabular}

cates that a definite and characteristic relationship exists between growing temperature and leaf age. When seedling muskmelon leaves are grown for 5 days at $15 \mathrm{C}$ vs. 5 days at $30 \mathrm{C}$, the plasma membrane from leaves grown at $15 \mathrm{C}$ initially has significantly less protein, more unsaturated than saturated fatty acids, more total phospholipids, but no significant difference in total sterols. As muskmelon leaves age from 5 to 10 days, regardless of growing temperature, the fatty-acid composition becomes more saturated and there is a further decline in plasma membrane total phospholipids. This results in an everincreasing sterol tophospholipid ratio. Although growing temperature has an impact on cell metabolism, it is secondary to aging in adapting the plasma membrane for thermostability (Lester, 1985), which indicates that cells from leaves grown under low vs. high temperatures will require different lengths of time to achieve equal physiological development and subsequent equal membrane thermostabilities. Others have reported similar membrane protein (Smaraka and Szarak, 1986), phospholipid (Kinney et al., 1987), sterol (Uemura and Yoshida, 1984), and fatty-acid ratio (Christianson, 1978) changes after growing plants at low vs. high temperatures. Also, lipid saturation has been directly linked to tomato leaf cell thermostability (Tal and Shannon, 1989).

In a heat injury study, Lester (1986) showed that, in 5-dayold 'Perlita' muskmelon leaves grown at 15 vs. 35C, then subjected to $50 \mathrm{C}$ for 15 rein, heat injury was $70 \%$ and $48 \%$, respectively. After 9 days at 15 or $35 \mathrm{C}$, heat injury of leaves was $35 \%$ and $20 \%$, respectively, indicating that thermostability of muskmelon leaves increases with age and that in 10-day-oId or older leaves, heat tolerance is not significantly affected by growing temperature (Lester, 1985). It would appear that inherent properties (probably enzymes) expressed with age are responsible for regulating the compositional molecular state of the plasma membrane and subsequent leaf thermostability.

The observed thermostability of Cucumis melo leaves (Lester, $1985,1986)$ appears to be a predetermined molecular event that, with age, develops the fluid state of the plasma membrane to function at relatively high growing temperatures.

\section{Literature Cited}

Arnon, D.I. 1949. Copper enzymes in isolated chloroplasts. Polyphenoloxidase in Beta vulgaris. Plant Physiol. 24:1-15.

Bennett, A.B., S.D. O'Neill, and R.M. Spanswick. 1984. H-ATPase activity from storage tissue of Beta vulagaris. Plant Physiol. 74:538544.

Bradford, M.M. 1976. A rapid and sensitive method for the quantitation of microgram quantities of protein utilizing the principle of protein dye binding. Anal. Biochem. 72:248-254.
Christiansen, M.N. 1978. The physiology of plant tolerance to temperature extremes, p. 173-191. In: G.A. Jung (cd). Crop tolerance to suboptimal land conditions. Amer. Soc. Agron., Madison, Wis. Gombos, Z. and L. Vigh. 1986. Primary role of the cytoplasmic membrane in thermal acclamation evidenced in nitrate-starved cells of the blue-green algae, Anacystis nidulans. Plant Physiol. 80:415419.

Hodges, T. K., R.T. Leonard, C.E. Bracker, and T.W. Keenan. 1972. Purification of and ion stimulated adenosine triphosphtase from plant roots: association with plasma membrane. Proc. Natl. Acad. Sci. USA 69:3307-3311.

Kinney, A. J., D.T. Clarkson, and B.C. Loughman. 1987. Phospholipid metabolism and plasma membrane morphology of warm and cool rye roots. Plant Physiol. Biochem. 25:769-774.

Kjellbom, P. and C. Larsson. 1984. Preparation and polypeptide composition of chlorphyll-free plasma membranes from leaves of light grown spinach and barley. Physiol. Plant. 62:501-509.

Klopfenstein, W.E. 1971. On methylation of unsaturated acids using boron trihalide-methanol reagents. J. Lipid Res. 12:773-776.

Lester, G.E. 1985. Leaf cell membrane thermostabilities of Cucumis melo. J. Amer. Soc. Hort. Sci. 110:506-509.

Lester, G,E. 1986. Physiology of melon leaf membrane thermostability during heat conditioning. J. Amer. Soc. Hort. Sci. 111:561-564.

Lester, G.E. and J.R. Dunlap. 1985. Physiological changes during development and ripening of 'Perlita' muskmelon fruit. Scientia Hort. 26:323-331.

Nagahashi, J. and T.S. Seibles. 1986. Preservation and separation of endo-membrane marker enzyme activity in potato leaf homogenates. Can. J. Bet. 64:2732-2737.

Peterson, G.L. 1978. A simplified method for analysis of inorganic phosphate in the presence of interfering substances. Anal. Biochem. 84:164-172.

Pierce, W.S. and D.L. Hendrix. 1979. Utilization of enzyme markers to determine the location of plasma membrane from Pisum sativum epicotyls on sucrose gradients. Planta 146:161-169.

Smaraka, A.V. and S.R. Szarek. 1986. Phonological temperature adaptation of protein turnover in desert annuals. Plant Physiol. 80:20r5210

Tal, M. and M.C. Shannon. 1983. Effect of dehydration and high temperature on the stability of leaf membranes of Lycopersicon esculentum, L. cheesmanii, L. peruvianum and Solarium pennellii. $Z$. Pflanzenphysiol. Bd. 112:411416.

Uemura, M. and S. Yoshida. 1984. Involvement of plasma membrane alterations in cold acclimation of winter rye seedlings (Secale cereal L. Cv. Puma). Plant Physiol. 75:818-826.

Yoshida, S. and M. Uemura. 1984. Protein and lipid composition of isolated plasma membranes from orchard grass (Dactylis glomerata L.) and changes during cold acclimation. Plant Physiol. 75:31-37.

Yoshida, S., T. Kawata, M. Uemura, and T. Niki. 1986. Properties of plasma membrane isolated from chilling-sensitive etiolated seedlings of Vigna radiata L. Plant Physiol. 80:152-160.

Zlatkis, A. and B. Zak. 1969. Study of a new cholesterol reagent. Anal. Biochem. 29:143-148. 